\title{
18 Carat White Gold Jewellery Alloys
}

\author{
SOME ASPECTS OF THEIR METALLURGY
}

\author{
Christian P. Susz and Michel H. Linker \\ U.G.D.O. - Usine Genevoise de Dégrossissage d'Or, Geneva, Switzerland
}

It is usual to distinguish between two types of white gold jewellery alloys according to the metal (nickel or palladium) primarily responsible for the 'bleaching' of the colour of the gold. The authors of this article point out that such differentiation is artificial from a metallurgical point of view. They illustrate the practical advantages of considering both nickel and palladium white golds as based on the gold-silver-palladium system.

\begin{abstract}
White gold jewellery alloys are usually classified according to caratage (or fineness) and to the element used to bleach the gold. Thus, it is customary to recognize two main families of such alloys, namely nickel-containing and palladium-containing white golds. Metallurgical aspects of the nickel-containing white golds - or, more accurately, the gold-coppernickel-zinc alloys - have recently been reviewed by McDonald and Sistare (1). Their approach was to relate the metallurgy of the complex commercial formulations that are popular in North America to features of the gold-copper-nickel ternary system (2).

Commerical palladium-containing white golds, like their nickel-containing counterparts, are complex alloys which often consist of more than four components. This complexity, together with the wide range of compositions commercially available, may explain the absence of a published classification of their metallurgical properties.
\end{abstract}

This article attempts to complement the review of McDonald and Sistare (1) with a corresponding review of palladium-containing white golds. From a metallurgical point of view, however, we have found the traditional distinction between nickel- and palladium-containing alloys to be somewhat artificial. White golds will therefore be discussed as a whole when considering the relationships between their composition and those of their properties that are of importance for jewellery manufacture. Such properties are primarily hardness, ductility, hardenability and colour.

\section{Nickel-Containing versus Palladium-Containing Alloys}

World-wide use of nickel-containing alloys is far greater than that of other white golds. However, these popular alloys have important limitations insofar as they cannot provide an adequate combination of good colour and workability $(3,4)$. If effective bleaching is achieved by substantial additions of nickel to a goldcopper matrix, then hardness is excessive even in the annealed condition, the work-hardening rate is high and frequent intermediate anneals are required during processing. Moreover, unless annealing conditions are very carefully controlled, nickel-rich gold alloys may fire-crack during heating or exhibit an 'orange-peel' effect upon further cold-working. Most of these detrimental properties arise from the equilibrium characteristics of the gold-copper-nickel ternary system which lead to solid state decomposition of the useful alloys into discrete gold-rich and nickel-rich phases $(1,2)$. An additional problem resulting from this phase separation may be diminished resistance to corrosion.

Partial or complete substitution of nickel by palladium greatly improves the properties of white gold alloys that are of importance for jewellery manufacture (3). Alloys containing both nickel and palladium are commercially available. Their adequate ductility, good colour and superior resistance to corrosion are definite technical advantages and they are therefore highly prized by many jewellery manufacturers in Europe, in spite of their higher cost.

\section{The Metallurgical System}

Irrespective of whether bleaching is achieved by use of nickel or palladium, or both, the metallurgy of white jewellery gold alloys can conveniently be discussed in terms of the addition of various elements to a gold-silver-palladium ternary matrix. Other components commonly present in commercial alloys are nickel, copper and zinc, but additions may also be made of indium, iron, platinum, cobalt and boron $(4,5)$.

Gold, silver and palladium are miscible in the solid state, irrespective of temperature or proportions. This property derives from the complete miscibility which 

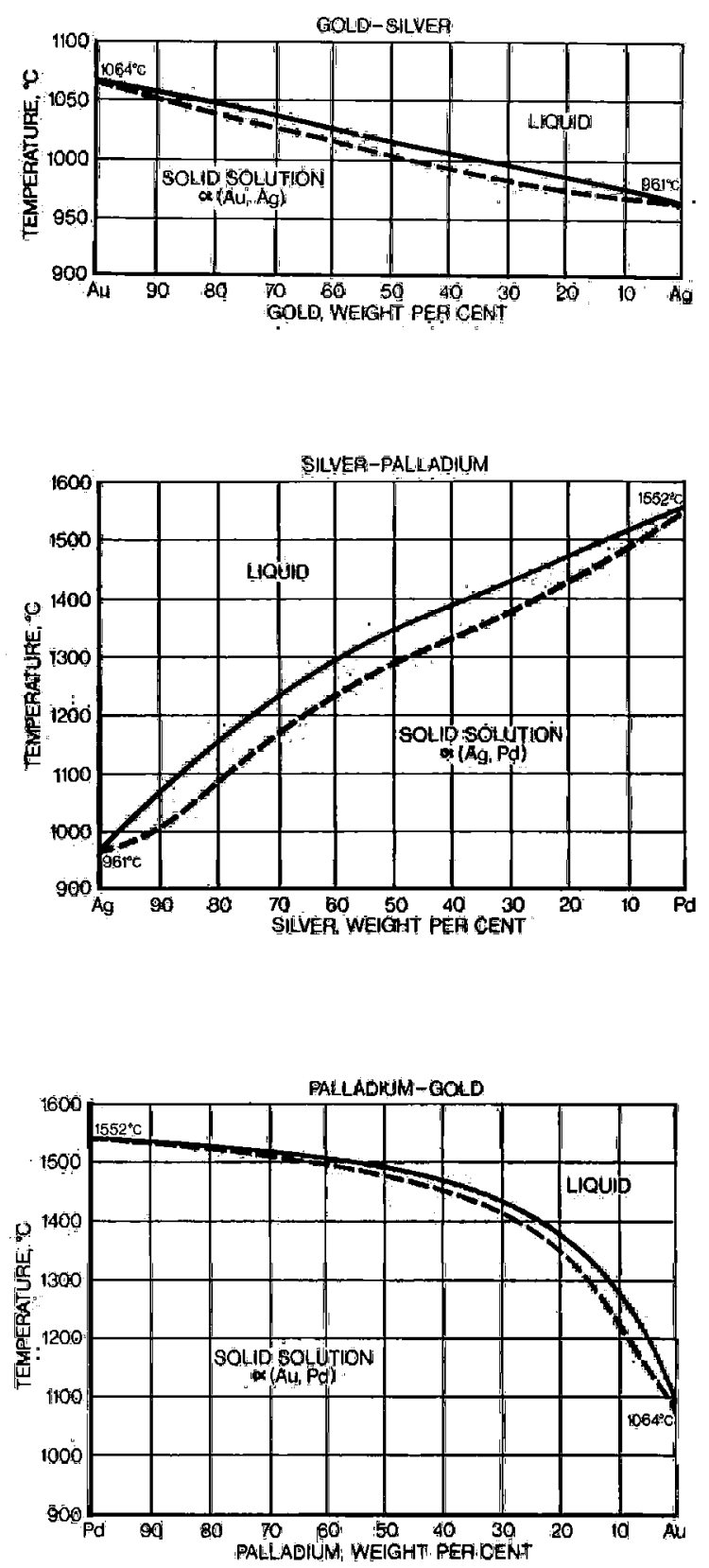

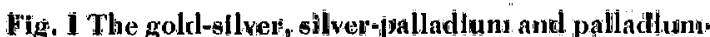
gold bluary phase diagraing show eomplete nutual solubility of these metals at all temperatures and in all proporitions. Thie metallurglcal beliapiour of teriary gold-silves palladium alloys is ilherefore yery binple. After (6)

characterizes the three binary systems formed by these metals (Figure 1). An important consequence of this behaviour is that most of the properties of the ternary alloys vary smoothly with, and are not critically dependent upon, composition. The constant hardness curves for fully annealed alloys, as shown in Figure 2, illustrate this feature of the ternary system. A conse-

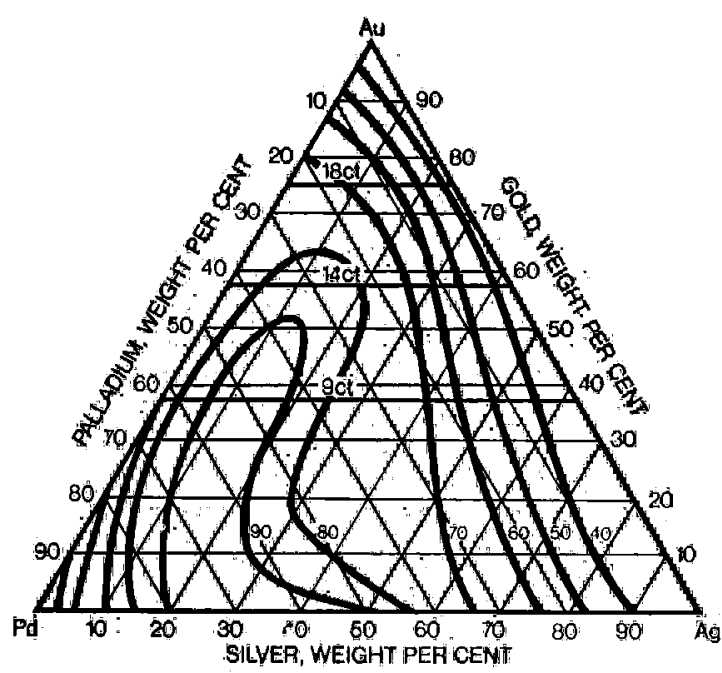

Fig. 2 Because of the complefe solid solubility of the three metals, properties of gold-silver-palladíun alloys are in general lititle affected hy their conrposition: This is illustrated here in respect of their Vickere hardness values. $H_{4}$ was measured on the alloys in the annealed condition. After $\mid(i)$

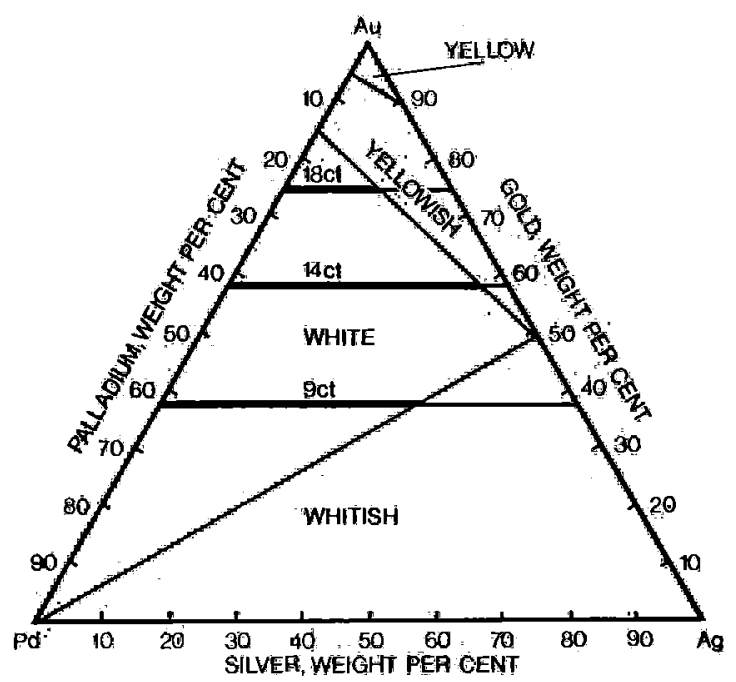

Fig. I Schematie tepresentalien of the relationship belween the compostiton and colour of ternary gold-stiver. palladium alloys. The bold stginents on the 9,14 and 18

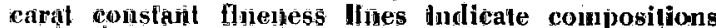
likely to constitule acceptablo inalrices for jewellery alloys of good colour: After (7)

quence is that many of the properties of white gold alloys are in large measure determined by the effects of additions to the gold-silver-palladium matrix. The nature and quantity of these additions may affect the lattice of the matrix and its mechanical properties. They may also determine the conditions under which the alloys can be age hardened. 
Table l:

Hardness Values and Erichsen Test Results Obtained from Soine 18 Carat Conmenclal* While Gold Alloys of Various Compasilions

\begin{tabular}{|c|c|c|c|c|c|c|c|}
\hline $\begin{array}{l}\text { Alloy: } \\
\text { type }\end{array}$ & $\begin{array}{c}\text { Comp } \\
\mathrm{Au}+\mathrm{Ag}+\mathrm{Pd}_{\mathrm{d}} \\
\text { wt: } \%\end{array}$ & $\begin{array}{l}\mathrm{Cu}+\mathrm{Ni}+\mathrm{Zn} \text {, } \\
\text { wt. } \%\end{array}$ & $\begin{array}{l}\text { Anne } \\
\text { hardness } \\
\text { value, } \\
H_{v}\end{array}$ & $\begin{array}{l}\text { and water-c } \\
\text { Erichsen" } \\
\text { strength, } \\
\text { kN }\end{array}$ & $\begin{array}{l}\text { hed } \\
\text { results } \\
\text { depth, } \\
\text { mm }\end{array}$ & $\begin{array}{c}\text { Côld-worked } \\
\text { (75\% } \\
\text { reduction) } \\
\text { hardness } \\
\text { value, } \\
\mathrm{H}_{u}\end{array}$ & $\begin{array}{l}\text { Alloy } \\
\text { code }\end{array}$ \\
\hline $\begin{array}{c}\text { Pd- } \\
\text { eontaining } \\
\text { Ni-free }\end{array}$ & 100 & 0 & 65 & 20.0 & 115 & 145 & A \\
\hline $\begin{array}{l}\mathrm{Pd} \text { - and } \mathrm{Ni}= \\
\text { containing }\end{array}$ & $\begin{array}{l}91 \\
91 \\
90.7 \\
90 \\
88 \\
83 \\
76.8\end{array}$ & $\begin{array}{l}9 \\
9 \\
9: 3 \\
10 \\
12 \\
17 \\
23: 2\end{array}$ & $\begin{array}{l}130 \\
170 \\
135 \\
180 \\
170 \\
200 \\
215\end{array}$ & $\begin{array}{l}32.5 \\
34.0 \\
33.5 \\
36.0 \\
38.0 \\
40.0 \\
45.0\end{array}$ & $\begin{array}{r}10.4 \\
9.2 \\
10.6 \\
10.5 \\
9.7 \\
9.1 \\
9.6\end{array}$ & $\begin{array}{l}250 \\
265 \\
235 \\
255 \\
275 \\
315 \\
340\end{array}$ & $\begin{array}{l}\text { B } \\
\text { C } \\
\text { D } \\
\text { E } \\
\text { F } \\
\text { G } \\
\text { H }\end{array}$ \\
\hline $\begin{array}{c}\text { Pd-free } \\
\text { Ni-containing }\end{array}$ & 75 & 25 & 220 & 47.0 & $10: 3$ & 340 & 1 \\
\hline
\end{tabular}

${ }^{*}$ Commercial alloys supplied by U.G.D.O., Geneva, Switżerland. $*$ See (8).

The strong influence of composition upon the colour of ternary gold-silver-palladium alloys is illustrated in Figure 3. This gives a schematic representation of trends (7) and reveals that at usual carat levels, only alloys with a restricted silver content have a good white colour. Thus, formulations with a high combined gold + palladium content will have the best appearance. Enhanced resistance to tarnish is an additional advantage of such formulations (7).

If first priority is given to the requirement of a good colour, the best gold-silver-palladium matrixes from which more complex 9,14 and 18 carat white alloys can be formulated are those indicated by bold lines on Figure 3. Therefore, discussion here will be limited to 18 carat white gold alloys containing less than 15 per cent silver by weight and in which adjustment of mechanical properties is obtained by additions of copper, nickel and zinc only.

\section{Hardness and Ductility}

The workability of a jewellery gold alloy is best reflected by its hardness and by its ductility as measured by a cupping test (8). Table I gives Vickers hardness values and Erichsen test results for nine white golds of compositions representative of 18 carat alloys commercially available in Europe. The combined copper + nickel + zinc contents of these alloys are between 0 and 25 per cent by weight. The data of Table $I$ are also plotted in Figure 4 against the total level of copper+nickel+zinc in the gold-silverpalladium matrix of each alloy. The correlation between the mechanical properties considered here and the total base metal contents of commercial white
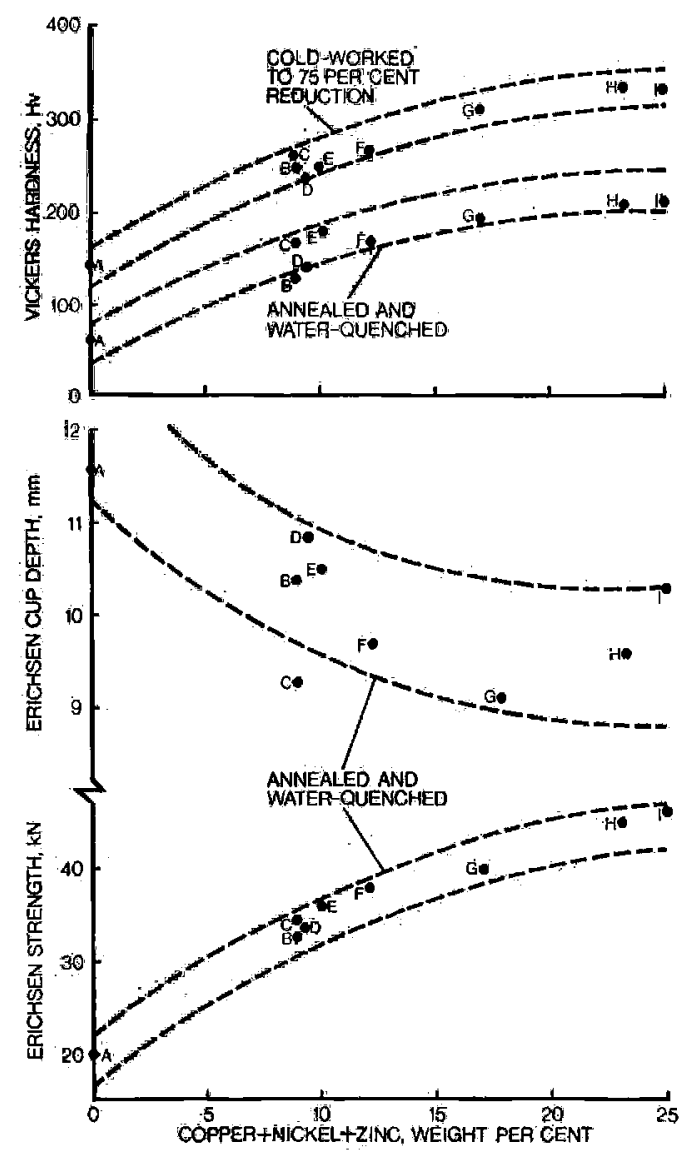

Fig. 4 Hardness values and Erichsen test results on some of the commercially available 18 caral white gold alloys listed in Table I. The experimental data are plotled against the total copper+nickel+zine contents in the gold-silver-palladium matrix. The annealing conditions used for this study were 30 minutes ail $730^{\circ} \mathrm{C}$ 


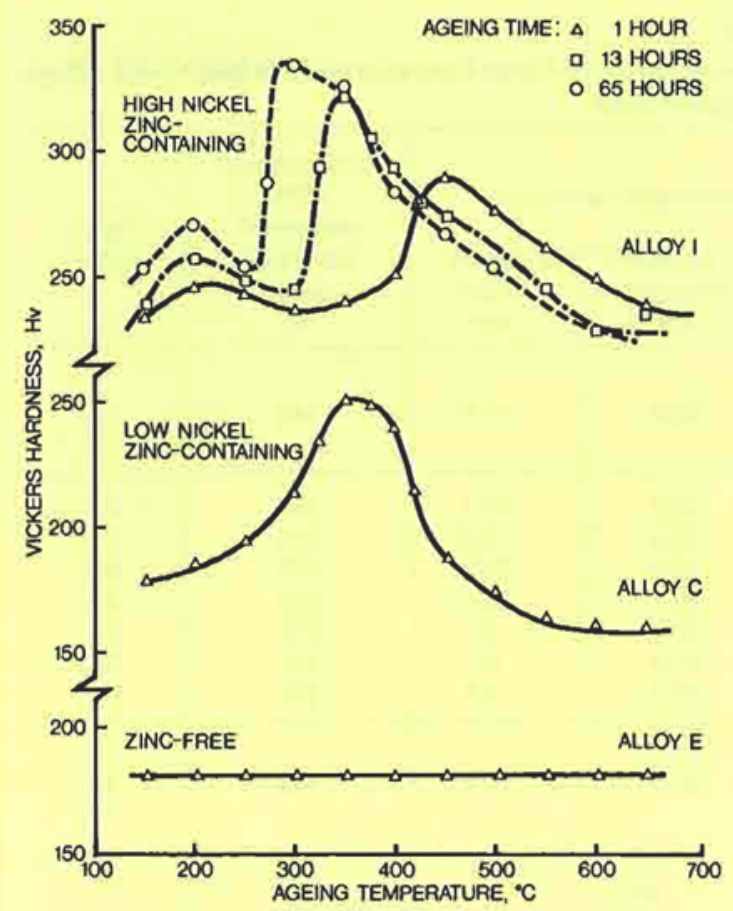

Fig. 5 Hardness values measured on three of the commercially available 18 carat white gold alloys listed in Table $I$, after ageing at temperatures between 150 and $700^{\circ} \mathrm{C}$ during 1,13 and 65 hours. The behaviour of alloys $E, C$ and $I$ is typical of that of zinc-free, zinc-containing but nickel-poor and zinccontaining nickel-rich alloys, respectively

golds is quite remarkable and confirms the initial statement that this latter variable is all important in determining the properties of these alloys. As the copper+nickel + zinc global content increases, so does the hardness of the 18 carat golds, whether this is measured in the annealed and water-quenched or in the cold-worked condition. Simultaneously, the ductility of the alloys in the annealed and water-quenched condition decreases.

It may therefore be concluded that, to a first approximation, the extent of strengthening of a goldsilver-palladium matrix by one or more of copper, nickel and zinc is determined only by the total level of the additions of these base metals. The respective proportions of copper, nickel and zinc in a commercial 18 carat white gold of given total gold +silver + palladium content do not greatly affect its mechanical properties. The proportions in which the two metals silver and palladium are present are likewise not highly significant.

\section{Hardenability}

Because most white jewellery gold alloys consist of at least four components, hardening mechanisms in them are complex and have not yet been fully explained. However, valuable information on such mechanisms can be provided by hardness measurements after ageing treatments. Thus, the results of such an investigation on three of the 18 carat alloys discussed in the previous paragraph are presented in Figure 5. Ageing temperatures were in the range of 150 to $700^{\circ} \mathrm{C}$ and ageing times extended from 1 to 65 hours. Comparison of the behaviour of three white golds reveals the important role played by zinc in age hardening. Zinc-free alloys are not susceptible to age hardening - the behaviour of alloy $\mathrm{E}$, as depicted in Figure 5 is typical in this respect. Conversely, all zinc-containing alloys are amenable to hardening by heat treatment, irrespective of their nickel and copper contents. The data in Figure 5, relating to the nickel-rich alloy $\mathrm{I}$, show that hardening may be slow to develop. This particular feature could explain why the phenomenon has so often been undetected.

Table II

Composition of Some 18 Carat White Gold Alloys of Various Origins. In Part after (5)

\begin{tabular}{|c|c|c|c|c|c|}
\hline $\begin{array}{l}\text { Alloy } \\
\text { type }\end{array}$ & $\begin{array}{r}\mathrm{N} \\
\mathrm{co} \\
\mathrm{Pd}+\mathrm{Zn} \\
\text { wt. \% }\end{array}$ & $\begin{array}{c}\text { ormalize } \\
\text { mpositio } \\
\mathrm{Cu}+\mathrm{Ag} \\
\text { wt. \% }\end{array}$ & $\begin{array}{l}\text { ed } \\
\text { nt. }^{*} \\
\text { wi } \%\end{array}$ & Origin & $\begin{array}{l}\text { Alloy } \\
\text { code }\end{array}$ \\
\hline $\begin{array}{c}\text { Pd- } \\
\text { Free } \\
\text { Ni- } \\
\text { con- } \\
\text { taining }\end{array}$ & \begin{tabular}{r|}
0.0 \\
17.3 \\
21.8 \\
14.9 \\
10.0 \\
20.9 \\
13.7 \\
17.1 \\
19.4 \\
20.0 \\
20.6 \\
14.8
\end{tabular} & $\begin{array}{r}0.0 \\
12.8 \\
8.7 \\
27.7 \\
40.0 \\
45.0 \\
52.2 \\
54.7 \\
54.4 \\
60.0 \\
65.2 \\
73.0\end{array}$ & $\begin{array}{r}100.0 \\
69.9 \\
69.5 \\
57.4 \\
50.0 \\
34.1 \\
34.1 \\
28.2 \\
26.2 \\
20.0 \\
14.2 \\
12.2\end{array}$ & $\begin{array}{l}\text { France } \\
\text { S. Africa } \\
\text { U.K./U.S.A. } \\
\text { Switz. } \\
\text { Italy } \\
\text { Spain } \\
\text { Italy } \\
\text { Germany } \\
\text { Italy } \\
\text { Italy } \\
\text { Italy } \\
\text { Italy }\end{array}$ & $\begin{array}{l}1 \\
2 \\
3 \\
4^{* *} \\
5 \\
6 \\
7 \\
8 \\
9 \\
10 \\
11 \\
12\end{array}$ \\
\hline $\begin{array}{c}\mathrm{Pd}- \\
\text { and } \\
\mathrm{Ni}- \\
\text { con- } \\
\text { taining }\end{array}$ & $\begin{array}{l}21.1 \\
18.9 \\
32.1 \\
62.0 \\
15.7 \\
44.0 \\
56.0 \\
20.8 \\
60.0 \\
51.4 \\
28.1 \\
60.7 \\
62.2 \\
39.4\end{array}$ & \begin{tabular}{r|}
30.8 \\
36.2 \\
41.8 \\
0.0 \\
48.4 \\
24.0 \\
12.0 \\
50.0 \\
12.0 \\
26.9 \\
53.8 \\
32.9 \\
31.7 \\
56.1
\end{tabular} & \begin{tabular}{r|}
48.1 \\
44.9 \\
26.1 \\
38.0 \\
35.9 \\
32.0 \\
32.0 \\
29.2 \\
28.0 \\
21.7 \\
18.1 \\
6.4 \\
6.1 \\
4.5
\end{tabular} & $\begin{array}{c}\text { Belgium } \\
\text { Switz. } \\
\text { Switz. } \\
\text { France } \\
\text { Germany } \\
\text { France } \\
\text { France } \\
\text { Germany } \\
\text { Switz. } \\
\text { Switz. } \\
\text { Switz. } \\
\text { Switz. } \\
\text { Switz. } \\
\text { U.K. }\end{array}$ & $\begin{array}{l}13 \\
14^{* *} \\
15^{* *} \\
16 \\
17 \\
18 \\
19 \\
20 \\
21^{* *} \\
22^{* *} \\
23^{* *} \\
24^{* *} \\
25^{* *} \\
26\end{array}$ \\
\hline $\begin{array}{l}\text { Pd- } \\
\text { con- } \\
\text { taining } \\
\text { Ni-free }\end{array}$ & $\begin{array}{l}80.0 \\
72.9 \\
65.1 \\
60.0 \\
51.5\end{array}$ & $\begin{array}{l}20.0 \\
27.1 \\
34.9 \\
40.0 \\
48.5\end{array}$ & $\begin{array}{l}0.0 \\
0.0 \\
0.0 \\
0.0 \\
0.0\end{array}$ & $\begin{array}{l}\text { Germany } \\
\text { U.K. } \\
\text { S. Africa } \\
\text { Switz. } \\
\text { S. Africa }\end{array}$ & $\begin{array}{l}27 \\
28 \\
29 \\
30^{* *} \\
31\end{array}$ \\
\hline
\end{tabular}

- Palladium + zinc + copper + silver + nickel $=100$ per cent by weight. True percentages in an 18 carat gold alloy are therefore $1 / 4$ the figures given in this Table.

* *Commercial alloy supplied by U.G.D.O., Geneva, Switzerland. 


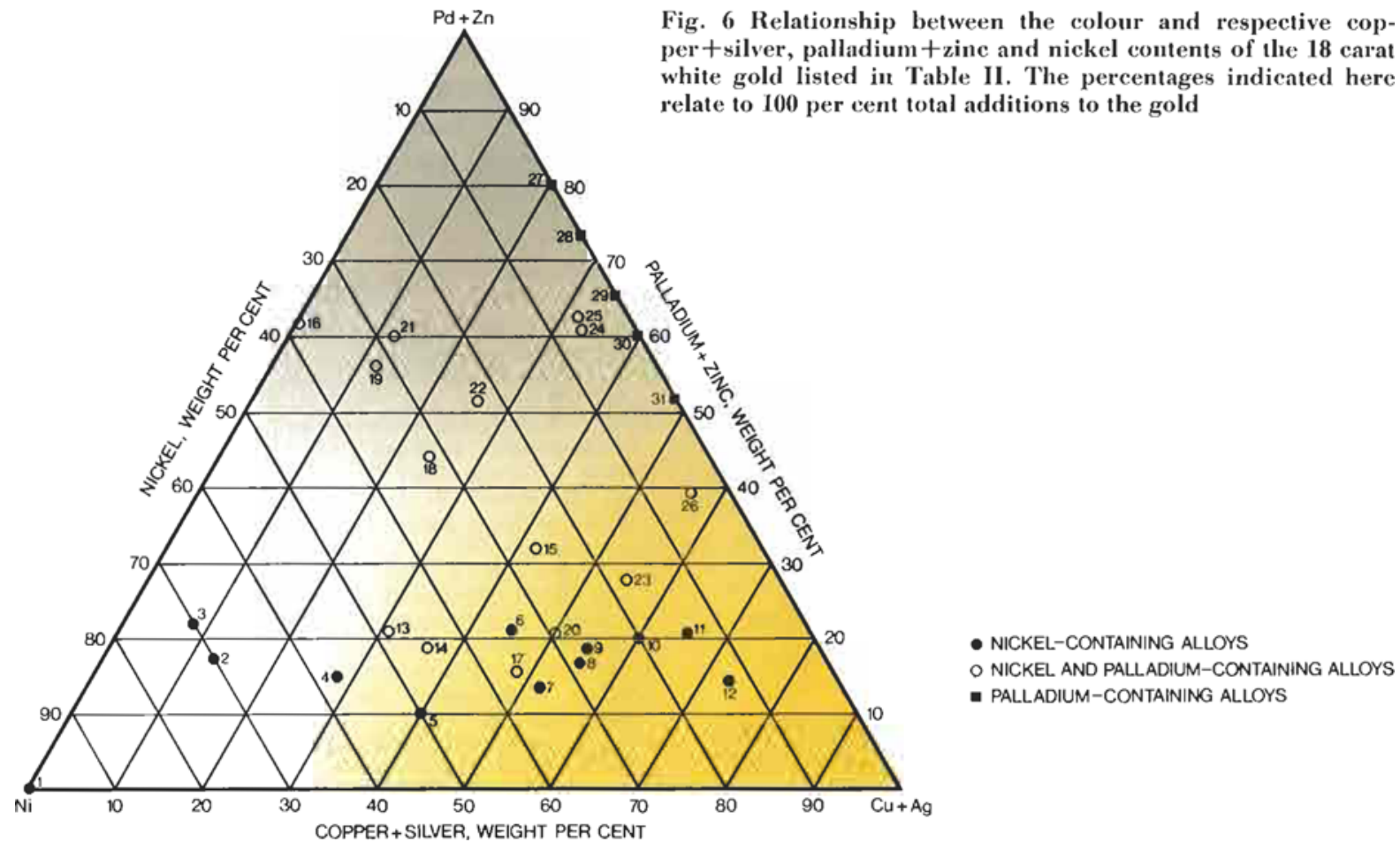

Labarge et al. (9) have previously reported on the importance of zinc in determining whether or not gold alloys are susceptible to age hardening. These authors attributed hardening in zinc-containing goldsilver-copper-platinum-palladium dental alloys to the precipitation of an $\mathrm{Au}_{3} \mathrm{Zn}$-type phase and to promotion of AuCu-type ordering by shearing of the original lattice. However, the results of the present study show that, if present, nickel also may participate in phenomena leading to hardening in zinccontaining alloys. Golds containing little nickel (such as alloy $\mathrm{C}$, Figure 5) are characterized by single-stage precipitation hardening, while those containing large additions of that metal (such as alloy I, Figure 5) are characterized by two-stage hardening. The first of these stages, which is observed only in nickel-rich alloys, develops during ageing at about $200^{\circ} \mathrm{C}$. The second and more significant hardening stage, which is common to all zinc-containing alloys irrespective of their nickel content, results in maximum hardness being attained only after ageing at temperatures in excess of $275^{\circ} \mathrm{C}$.

The authors of the present article are furthering their studies of the kinetics of solid state transformations in complex commercial 18 carat white golds with the ultimate aim of identifying the phases responsible for these age hardening effects.

\section{Colour}

The known effects of various metals on the colour of gold alloys in which they are incorporated in significant proportions are as follows:
- Silver bleaches weakly

- Palladium and zinc impart a good white colour with desirable warm grey overtones

- Nickel imparts a cold, white 'steely' aspect.

The combined effect of more than one of these metals when they are present together in gold, as is the case in commercial jewellery alloys, is more difficult to define. A simple colour diagram may however be established if the variables considered are:

- The global silver + copper concentration, which indicates the absence of bleaching effect

- The global palladium +zinc concentration, which indicates bleaching towards an attractive grey-white colour

- The nickel concentration, which indicates bleaching towards a 'steely' colour.

For convenience, the total of these three components can be normalized to 100 per cent, instead of 25 per cent in an 18 carat alloy. The ternary diagram of Figure 6 has been established in this manner. The positions of the 31 jewellery alloys listed in Table II - all of which are 18 carat white golds, originating from nine different countries (5) - are indicated on this diagram.

Bearing in mind that the zinc content of 18 carat white golds has to be restricted to avoid excessive oxidation during heat treatment and that, for reasons detailed above, the silver content has to be less than 15 per cent by weight ( 60 per cent of the total additions to an 18 carat alloy), the necessity for substantial additions of palladium to achieve an attractive colour is clearly apparent from Figure 6. 


\section{Conclusions}

The main conclusion drawn from the considerations and experimental data discussed here is that 18 carat white jewellery gold alloys as a whole can with advantage be considered in relation to the ternary gold-silver-palladium system. On this basis, their mechanical properties can be directly correlated with their total copper + nickel + zinc content, irrespective of the precise composition of the gold-silverpalladium matrix, and alloys devoid of either nickel or palladium can be viewed as extreme cases only.

While the presence of zinc is an essential requirement for any form of age hardening to take place in these alloys, the nature of the mechanisms leading to this hardening, as well as its extent, are affected by the nickel concentration. The solid state reactions responsible for age hardening are slow and heat treatment lasting several tens of hours may be required to reach equilibrium.

The best compromise between mechanical properties and colour is achieved in 18 carat alloys con- sisting of six components, namely gold, silver, palladium, copper, nickel and zinc. The colour diagram proposed here enables the prediction of the colour of new formulations incorporating these six components, in spite of their complexity.

\section{References}

1 A. S. MeDonald and G. H. Sistare, Gold Bull., 1978, 11, (3), 66-73 and (4), 128-131

2 E. Raub and A. Engel, Metallforsch, 1947, 2, 11-16 and $147-158$

3 W. S. Rapson and 'T. Groenewald, 'Gold Usage', Academic Press, L.ondon, 1978, pp. 41-49

4 G. P. O'Connor, Gold Bull., 1978, 11, (2), 35-39

5 T. Groenewald, R. W. Quail and E. Krugel, Chamber of Mines of Sourh Africa, Research Organisation, private communication, 1977

$6 \mathrm{M}$. Hansen and $\mathrm{K}$. Anderko, 'Constitution of Binary Mlloys', 2nd edition, McGraw-Hill Book Co., Inc., New York, 1958

7 J. Halner and R. Volterra in 'Metals Handbook', vol. 1, 8th edition, American Society for Metals, 1961, p. 1195

8 Deutsche Industrie Normen, DIN 50101, 1961; after International Organization for Standardization, ISO-Recommendation 149-1960

9 J.-J. Labarge, D. Tréheux and P. Guiraldenq, Gold Bull., $1979,12,(2), 46-52$

\section{New Facility for Refining of Precious Metals}

Johnson Matthey Chemicals Limited, international refiners of precious metals, have announced the introduction of substantial improvements and extensions to the company's precious metals refining facilities with the opening of a new installation at Brimsdown, near Enfield, England. The new plant is complementary to the company's Royston facility where precious metals are further refined to purities of up to 99.99 per cent.

The input materials cover the full range of precious metal-bearing concentrates, residues, bullion, scrap and waste material from industrial consumers in the jewellery, photographic, electronics, chemical and decorative industries.
The precious metal refining business is unique in that the customer often has no accurate knowledge of the value of the material he delivers for refining. This places a heavy responsibility on the refiner, especially as the material varies considerably in form, homogeneity and content of valuable metals. Particular attention has therefore been given at Brinssdown to facilities which enable material to be converted to a state from which truly representative samples can be taken for precious metals assays. The most modern equipment has also been installed for such assays.

We hope to be able to present an account of the procedures and refining processes used in precious metal recovery in a future issue of Gold Bulletin.

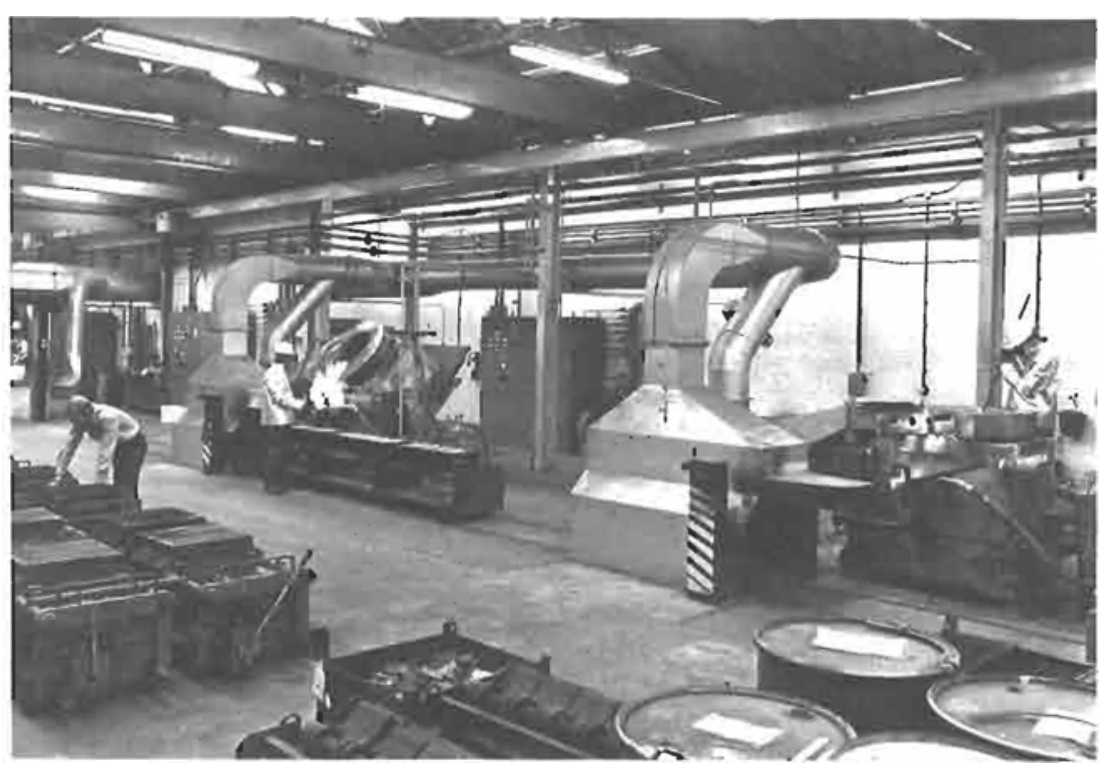

Two of the nine electrical induction furnaces recently commissioned at Johnson Matthey Chenicals precious metals refinery at Brinsdown are visible in this partial view of the melting house 